\title{
FACTORS AFFECTING HELICOBACTER PYLORI ERADICATION USING A SEVEN-DAY TRIPLE THERAPY WITH A PROTON PUMP INHIBITOR, TINIDAZOLE AND CLARITHROMYCIN, IN BRAZILIAN PATIENTS WITH PEPTIC ULCER
}

Fernando Marcuz Silva, Schlioma Zaterka, Jaime Natan Eisig, Ethel Zimberg Chehter, Décio Chinzon and Antonio Atílio Laudanna

RHCFAP/3030

SILVA FM et al. - Factors affecting Helicobacter pylori eradication using a seven-day triple therapy with a proton pump inhibitor, tinidazole and clarithromycin, in brazilian patients with peptic ulcer Rev. Hosp. Clín. Fac. Med. S. Paulo 56(1):11-16, 2001.

Triple therapy is accepted as the treatment of choice for H. pylori eradication. In industrialized countries, a proton pump inhibitor plus clarithromycin and amoxicillin or nitroimidazole have shown the best results. Our aims were: 1 . To study the eradication rate of the association of a proton pump inhibitor plus tinidazole and clarithromycin on $H$. pylori infection in our population. 2 . To determine if previous treatments, gender, age, tobacco, alcohol use, and non-steroidal anti-inflammatory drugs (NSAIDs) change the response to therapy.

Methods: Two hundred patients with peptic ulcer (upper endoscopy) and H. pylori infection

(histology and rapid urease test — RUT) were included. A proton pump inhibitor (lansoprazole $30 \mathrm{mg}$ or omeprazole $20 \mathrm{mg}$ ), tinidazole $500 \mathrm{mg}$, and clarithromycin $250 \mathrm{mg}$ were dispensed twice a day for a seven-day period. Eradication was assessed after 10 to 12 weeks of treatment through histology and RUT.

Results: The eradication rate of $H$. pylori per protocol was $65 \%$ (128/196 patients). This rate was $53 \%$ for previously treated patients, rising to $76 \%$ for not previously treated patients, with a statistical difference $p<0.01$. No significant difference was observed regarding sex, tobacco use, alcohol consumption, and NSAID use, but for elderly patients the difference was $p=0.05$. Adherence to treatment was good, and side effects were mild.

Conclusions: A proton pump inhibitor, tinidazole, and clarithromycin bid for seven days resulted in $H$. pylori eradication in $65 \%$ of the patients. Previous treatments were the main cause of treatment failure.

DESCRIPTORS: Peptic Ulcer Treatment. Helicobacter pylori Eradication. Proton pump inhibitor. Tinidazole. Clarithromycin.

The identification of $H$. pylori in the gastric epithelium and its relationship with peptic disease ${ }^{1}$ resulted in a remarkable change in the management of peptic ulcers. It is a worldwide consensus that eradication of the bacterium is the corner stone of peptic ulcer cure ${ }^{2,3}$. The low rates of eradication observed in mono therapies and double therapies have encouraged the use of three antibiotics or two antibiotics and a proton pump inhibitor ${ }^{4,5,6}$ Efficacy, the short period of treatment, low doses, few side effects, and low cost, make triple therapy with a proton pump inhibitor, macrolide, and nitroimidazole a very acceptable treatment for $H$. pylori eradication $^{7,8,9}$. In Brazil, as well as in all de-

From the Department of Gastroenterology, Hospital das Clínicas, Faculty of Medicine, University of São Paulo. veloping countries, the risk of a therapeutic failure because of $H$. pylori strains that are resistant to metronidazole has to be considered ${ }^{7}$, because of its worldwide use. The aim of our study was to observe the eradication rate of $H$. pylori in a Brazilian peptic ulcer population under this treatment. The influence of previous treatments, gender, age, tobacco, alcohol, and NSAID use on therapy was evaluated. 


\section{PATIENTS AND METHOD}

Two hundred outpatients seen from December 1995 to September 1996 were invited to participate. Inclusion criteria: 1. Patients with gastric or duodenal peptic ulcer (active or healed). 2. $H$ pylori infection diagnosed by both histology and RUT. 3 . Patients with no previous treatment and previously treated with bismuth subcitrate, metronidazole, and amoxicillin or tetracycline. Exclusion criteria: 1 . Patients under 16 years of age. 2. Previous use of antibiotic therapy at least three months prior to the inclusion. 3. Pregnant or lactating women. 4. Prior gastric surgery. 5. Patients with any decompensated_disease.

The Ethical and Scientific Committee of Hospital das Clinicas approved this protocol. Before inclusion, all participants signed a post-informed consent statement.

Patients' data were obtained from standard questionnaires conducted at patients' inclusion in the study.

$H$. pylori infection was confirmed by histological examination (H\&E and Giemsa methods) and rapid urease test (RUT) performed on biopsy material taken during upper endoscopy (2 samples of antrum and 2 samples of gastric body). H. pylori was considered eradicated when the RUT and histological examination performed 10 to 12 weeks after the end of the treatment were negative.

Clarithromycin $250 \mathrm{mg}$ plus tinidazole $500 \mathrm{mg}$ and a proton pump inhibitor (lansoprazole $30 \mathrm{mg}$ or omeprazole $20 \mathrm{mg}$ ) were dispensed twice a day for a seven-day period. After treatment, compliance was assessed by pill consumption. Patients were asked about adverse effects. Patients were requested to stop all medications except antacids if needed for dyspeptic symptom relief or other medications for chronic use in concomitant diseases.
Statistical analysis was performed with software package SPSS v.3.0 (SPSS Inc., USA). The variables, gender, age, previous treatment, tobacco, alcohol, and NSAIDs were analyzed by the chi-square method. A p value < 0.05 was taken as being significant. A multiple logistic regression analysis was also performed; eradication was the dependent variable, and gender, age, previous treatment, tobacco, alcohol, and NSAIDs were the independent variables.

\section{RESULTS}

Two hundred patients were included in the study. There were 196 patients available for analysis "per protocol", most of them female with mean age $=44$ (range $=16$ to 80 ). The demographic data are shown in table 1 .

Side effects were observed in 36 patients (18\%), usually mild ones. One patient had to stop medication because of severe nausea and vomiting. Taste alterations, nausea, diarrhea, and dizziness were the most frequent side effects observed. One patient reported glossitis and vulvae pruritus.

Patients' adherence was high. All except 3 patients took more than $90 \%$ of the pills.

H. pylori was eradicated in 128 of $196(65 \%)$ patients (Table 2). Therapy efficacy depended on the previous treatment. For patients previously treated, eradication percentage was $53 \%$ (49/92), rising to $76 \%(79 / 104)$ for untreated patients, a statistically significant difference $(p<0.01)$. Eradication rate was different in males: $71 \%$ (53/75) when compared to females: $62 \%(75 / 121)$, without a statistical difference $(\mathrm{p}=0.21)$. Eradication was not affected by the use of tobacco (61\% x 67\%), alcohol (63\% x 72\%), or NSAIDs (69\% x 64\%). The rate for patients over 44 years: $73 \%(62 / 85)$ was higher than for those under 44 : $60 \%(66 / 111)$, with $\mathrm{p}$ value $=0.05$ (Table 3).

Table 1 - Clinical data.

\begin{tabular}{lrr}
\hline Age over 44 & $\mathbf{4 4 \%}$ & $(87 / 200)$ \\
Female & $\mathbf{6 2 \%}$ & $(123 / 200)$ \\
Previous treatment & $\mathbf{4 7 \%}$ & $(93 / 200)$ \\
Smokers & $\mathbf{3 6 \%}$ & $(70 / 195 *)$ \\
NSAID Users & $\mathbf{1 6 \%}$ & $(32 / 198 *)$ \\
Alcohol Users & $\mathbf{1 5 \%}$ & $(29 / 193 *)$ \\
\hline
\end{tabular}

* missing data

Table 2 - Eradication rates.

\begin{tabular}{|c|c|c|}
\hline & $\%(\mathrm{n})$ & CI $(95 \%)$ \\
\hline Intention to treat & $\mathbf{6 4 \%}(128 / 200)$ & $57 \%-70 \%$ \\
\hline "Per protocol" & $\mathbf{6 5 \%}(128 / 196)$ & $58 \%-72 \%$ \\
\hline
\end{tabular}


Table 3 - "Per Protocol" eradication rates.

\begin{tabular}{|c|c|c|c|c|}
\hline Variable & & & & $\mathrm{p}$ \\
\hline Tobacco & $\begin{array}{c}\text { users } \\
61 \% \\
(42 / 69)\end{array}$ & $\begin{array}{c}\text { non-users } \\
67 \% \\
(82 / 123)\end{array}$ & 0.42 & \\
\hline Alcohol & $\begin{array}{c}\text { users } \\
72 \% \\
(21 / 29)\end{array}$ & $\begin{array}{c}\text { non-users } \\
63 \% \\
(102 / 161)\end{array}$ & 0.27 & \\
\hline NSAID & $\begin{array}{c}\text { users } \\
69 \% \\
(22 / 32)\end{array}$ & $\begin{array}{c}\text { non-users } \\
64 \% \\
(105 / 163)\end{array}$ & 0.63 & \\
\hline Gender & $\begin{array}{c}\text { male } \\
71 \% \\
(53 / 75)\end{array}$ & $\begin{array}{c}\text { female } \\
62 \% \\
(75 / 121)\end{array}$ & 0.21 & \\
\hline Age (yrs) & $\begin{array}{c}<44 \\
60 \% \\
(66 / 111)\end{array}$ & $\begin{array}{c}\geq 44 \\
73 \% \\
(62 / 85)\end{array}$ & 0.05 & \\
\hline Previous treatment & $\begin{array}{c}\text { with } \\
53 \% \\
(49 / 92)\end{array}$ & $\begin{array}{c}\text { without } \\
76 \% \\
(79 / 104)\end{array}$ & $<0.01$ & \\
\hline
\end{tabular}

\section{DISCUSSION}

The objective of $H$. pylori-dependent peptic ulcer treatment should be healing the ulcer and eradication of the bacteria. Many treatment schedules have been suggested to eradicate $H$. $p y$ lori ${ }^{6,10,11}$. Eradication success depends mainly on adherence to treatment and bacterial resistance to medications ${ }^{12-15}$. There is no doubt that the ideal treatment must be effective at a low cost, besides being simple and free of side effects. It is a consensus in developed countries that an acceptable eradication rate is $90 \%$ or more ${ }^{2,9,11,16}$. Triple therapy with a proton pump inhibitor was considered the treatment of choice to eradicate $H$. pylori $i^{2,3,17-23}$. Association of a proton pump inhibitor plus amoxicillin or nitroimidazole and clarithromycin results in an eradication rate higher than $90 \%{ }^{6,8,11,17,18,20-22}$. In populations where resistance to metronidazole is more than $30 \%$, low ef- fectiveness has been reported ${ }^{13,14}$. In Brazil, H. pylori resistance to metronidazole is over $30 \%^{7}$, so it was not surprising that the $90 \%$ success rate in eradication was not reached by our population $^{24-27}$. In our study, the compliance to treatment was good; all except 3 patients took more than $90 \%$ of the pills. Although we do not have data on bacteria sensitivity, the $76 \%$ eradication rate observed in the first treated patients was probably due to tinidazole resistance. Similarly, a greater proportion of metronidazole-resistant strains present in patients underwent treatment for the second time, could explain the low $53 \%$ eradication rate observed. Moshkowitz ${ }^{28}$ obtained similar data. These results reinforce that it is preferable that nitroimidazoles not be used in triple therapy schedules in Brazil. Macheda and Zaterka (unpublished results) and Chehter et al. ${ }^{29}$ obtained $85 \%$ eradication in patients undergoing 7 day treatment with lansoprazole $30 \mathrm{mg}$ plus amoxicillin $1.0 \mathrm{~g}$ and clarithromycin $0.5 \mathrm{~g}$ bid. They show that the use of amoxicillin instead of tinidazole increases the eradication rate, which is similar to the results observed in developed countries. Side effects were reported by $18 \%$ of our patients, usually mild ones, therefore not interfering with adherence to treatment. Only one patient with persistent nausea and vomiting resulted in withdrawal from treatment. As observed by other investigators, we expected to find a higher eradication rate in males, since women would theoretically have been exposed to treatment with nitroimidazoles ${ }^{30,31}$ more often, and consequently would show a higher resistance to tinidazole. However, the eradication rate was similar in males and females. It is possible that males and females are equally exposed to the previous use of nitroimidazole in Bra$\mathrm{zil}^{7}$.

In a recent work $^{32}$, smoking was a predictive factor of treatment failure, but our study failed to confirm this, in agreement with the Kadayifçi report ${ }^{33}$.

Alcohol and NSAID use did not influence the outcome of eradication therapy.

There was a predominance of women in our study, which is a rule in all outpatient services in Brazil ${ }^{34}$. We cannot rule out an increase in female prevalence of peptic ulcer as partially responsible for the increased number of women in our study. An increased incidence of women with peptic ulcer disease has been reported in the USA since $1980^{35,36}$. The better eradication rate of therapy for patients over 44 years old is difficult to explain. Similarly, Cutler and Schubert ${ }^{27}$ and Labens ${ }^{37}$ also observed this response in elderly patients. Nevertheless, Moayyedi ${ }^{31}$ did not find any influence of age on eradication rate using a treatment schedule similar to ours. 
SILVA FM e col. - Fatores que afetam a erradicação do Helicobacter pylori usando um tratamento triplo de sete dias com um inibidor de bomba de prótons associado ao tinidazol e a claritromicina, em pacientes brasileiros com úlcera péptica. Rev. Hosp. Clín. Fac. Med. S. Paulo 56(1):11-16, 2001.

O esquema tríplice tem sido demonstrado como sendo o melhor tratamento para a erradicação do Helicobacter pylori. Nos países industrializados o uso de um inibidor de bomba de prótons associado a claritromicina e a amoxicilina ou a um nitroimidazólico, tem proporcionado os melhores resultados. Objetivamos estudar na nossa população a taxa de erradicação do $H$. pylori para a associação de um inibidor de bomba de prótons com o tinidazol e a clari- tromicina e determinar se a resposta ao tratamento é influenciada pelo tratamento prévio, sexo, tabagismo, alcoolismo, idade e uso de anti-inflamatórios não esteroidais (AINEs).

Pacientes e procedimentos: Duzentos pacientes com diagnóstico endoscópico de úlcera péptica e com infecção pelo $H$. pylori, confirmada pelo exame histológico e pelo teste rápido da urease (TRU), foram incluídos no estudo. Um inibidor de bomba de prótons (lansoprazol 30mg ou omeprazol 20 $\mathrm{mg}$ ), tinidazol $500 \mathrm{mg}$ e claritromicina $250 \mathrm{mg}$ foram ministrados duas vezes ao dia, por um período de 7 dias. A erradicação era determinada depois de 10 a 12 semanas após o fim do tratamento, por histologia e TRU.

Resultados: O percentual de erradicação do $H$. pylori (por protocolo) foi de $65 \%$ (128/196 pacientes). Para pacientes previamente tratados o valor foi de $53 \%$, aumentando para $76 \%$ nos pacientes não previamente tratados com diferença estatística $(p<0,01)$. Não houve diferença significativa para sexo, tabagismo, alcoolismo e uso de AINEs, mas para pacientes de mais idade houve diferença com $p=0,05$. A aderência ao tratamento foi boa e os efeitos adversos, leves.

Conclusão: $\mathrm{O}$ esquema inibidor de bomba de prótons, tinidazol e claritromicina, dados duas vezes ao dia por 7 dias proporcionou erradicação do $H$. pylori em $65 \%$ dos pacientes. O tratamento prévio foi o principal fator para seu insucesso.

DESCRITORES: Tratamento da úlcera péptica. Erradicação do Helicobacter pylori. Inibidor de bomba de prótons. Tinidazol. Claritromicina.

\section{REFERENCES}

1. WARREN JR \& MARSHALL BJ - Unidentified curved bacilli on gastric epithelium in active chronic gastritis. Lancet 1983: 12735 .

2. NATIONAL Institutes of Health Consensus Development Conference Statement. Helicobacter pylori in peptic ulcer disease. JAMA 1994; 272: $65-9$.

3. CONSENSO Nacional sobre Helicobacter pylori e afecções associadas. GED 1996; 15: 53-9.
4. MARSHALL BJ - Treatment strategies for Helicobacter pylori infection. Gastroenterol Clin North Am 1993; 22: 183-98.

5. HUNT RH - Helicobacter pylori eradication: A critical appraisal and current concerns. Scand J Gastroenterol 1995; 30 (Suppl 210): 73-6.

6. UNGE P \& BERSTAD P - Pooled analysis of anti-Helicobacter pylori treatment regimens. Scand J Gastroenterol 1996; 31(Suppl 220): 27-40. 
7. BAZZOLIF, GULLINI S, ZAGARINI RM et al. - Effect of omeprazole and clarithromycin plus tinidazole on the eradication of Helicobacter pylori and the recurrence of duodenal ulcer. Am J Gastroenterol 1994; 89: A316.

8. FENNERTY MB - What are the treatment goals for Helicobacter pylori infection? Gastroenterol 1997; 113 (suppl1): 120-5.

9. UNGE P - What other regimens are under investigation to treat Helicobacter pylori infection? Gastroenterol 1997; 113 (Suppl 1): $131-48$

10. QUEIROZ DMM, COIMBRA RS, MENDES EN ROCHA et al. Metronidazol resistant Helicobacter pylori in a developing country. Am J Gastroenterol 1993; 88: 322-3.

11. VAN DER HULST RWM, KELLER JJ, RAUWS, EAJ et al. Treatment of Helicobacter pylori infection: A review of the world literature. Helicobacter 1996, 1: 6-19.

12. GLUPCZYNSKY Y, LABBÉ M, VAN DER LINDEN MP et al. - Lack of antibiotic compliance in patients treated for Campilobacter pylori-associated gastritis. Am J Gastroenterol 1989; 84: 1126.

13. GRAHAM DY, LEW GM, MALATY HM et al. - Factors influencing the eradication of Helicobacter pylori with triple therapy. Gastroenterol 1992; 102: 943-6.

14. GLUPCZYNSKY Y \& BURETTE A. - Drug therapy for Helicobacter pylori Infection: Problems and pitfalls. Am J Gastroenterol 1990; 85: $1545-51$

15. BELL GD, POWELL KU, BURRIDGE SM et al. - Reinfection or recrudescence after apparently successful eradication of Helicobacter pylori infection: implications for treatment of patients with duodenal ulcer disease. Q J Med 1993; 86: 375-82.

16. TYTGAT GN - Treatments that impact favorably upon the eradication of Helicobacter pylori and ulcer recurrence. Aliment Pharmacol Ther 1994; 8:4, 359-68.

17. LABENS J, PEITZ U, TILLENBERG B et al. - Short term triple therapy with pantoprazole, clarithromycin and metronidazole for eradication of Helicobacter pylori. Laber Magen Darm 1995; 25: 125-7.

18. LIND T, VELDHUYZEN VAN ZANTEN S, UNGE P et al. Eradication of Helicobacter pylori using one-week triple therapies combining omeprazole with two antimicrobials: the MACH I Study. Helicobacter 1996; 1: 138-44.

19. GODDARD AF \& SPILLER RC - Helicobacter pylori eradication in clinical practice: one-week low-dose triple therapy is preferable to classical bismuth-based triple therapy. Aliment Pharmacol Ther 1996; 10:1009-13
20. CURRENT European concepts in the management of Helicobacter pylori infection. The Maastrich Consensus Report. European Helicobacter pylori Study Group. Gut 1997, 41: 8-13.

21. LAM SK \& TALLEY NJ - Report of the 1997 Asia Pacific Consensus. Conference on the management of Helicobacter pylori infection. J Gastroenterol Hepatol 1998, 13: 1-12.

22. HUNT RH, FALLONE CA \& THOMSON AB - Canadian Helicobacter pylori Consensus Conference Update: infections in adults. Canadian Helicobacter Study Group. Can J Gastroenterol 1999, 13: 213-7.

23.ZUBERI BF, LAL S \& SHEIKH RM TI. - Low dose, short-term, triple therapy for Helicobacter pylori associated peptic ulcer. JPMA J Pak Med Assoc 1997; 47: 228-30.

24. COELHO LGV, PASSOS MCF, CHAUSSONY et al. - Duodenal ulcer and eradication of Helicobacter pylori in a developing country. An 18-month follow-up study. Scand J Gastroenterol 1992; 27: 362-66.

25. COELHO LGV, PASSOS MCF, CHAUSSON Y et al. - One-week US $\$ 12.00$ therapy heals duodenal ulcer and eradicates Helicobacter pylori. Gastroenterology 1992; 102 (Suppl 11): A51.

26. FRANCO JMM, CASTRO FJ, PASSOS MCF et al. - Helicobacter pylori: erradicação em curto prazo com o esquema Belo Horizonte modificado. GED 1994; 13: 81-4.

27.ZATERKA S, EISIG JN, CHINZON D et al. - Five-day and ten-day triple therapy (amoxicillin, furazolidone and metronidazole) in the treatment of duodenal ulcer. Rev Hosp Clin Fac Med S Paulo 1996; 51: 162-5.

28. MOSHKOWITZ M, KONIKOFF FM, PELED Y et al. - One week triple therapy with omeprazole, clarithromycin and tinidazole for Helicobacter pylori: differing efficacy in previously treated and untreated patients. Aliment Pharmacol Ther 1996; 10:1015-9.

29. CHEHTER EZ, SILVA FM, EISIG JN et al. - H. pylori eradication: High efficacy week treatment with clartithromycin $500 \mathrm{mg}$ bid, amoxicillin $1.0 \mathrm{~g}$ bid plus lansoprazole $30 \mathrm{mg}$ bid in São Paulo Brazil. Am J Gastroenterolol 1999, 94: A118.

30. SEPPALA K, FARKKILA M, NUUTINEN $\mathrm{H}$ et al. - Triple therapy of Helicobacter pylori infection in peptic ulcer - A 12-month followup study of 93 patients. Scand J Gastroenterol 1992; 27: 973-6.

31. MOAYYEDI P, CHALMERS DM \& AXON AT - Patient factors that predict failure of omeprazole, clarithromycin, and tinidazole to eradicate Helicobacter pylori. J Gastroenterol 1997; 32: 24-7.

32. CUTLER AF \& SCHUBERT TT - Patient factors affecting Helicobacter pylori eradication with triple therapy. Am J Gastroenterol 1993; 88: 505-9. 
33. KADAYIFÇI A \& SIMESEK H - Does smoking influence the eradication of Helicobacter pylori and duodenal ulcer healing with different regimens? In J Clin Pract 1997; 51: 516-7.

34. DUNCAN BB \& NENGUE SS - Aspectos das condições de saúde da população brasileira. In: DUNCAN BB, SCHMIDT MI \& GIUGLIANI ERJ, eds. - Medicina Ambulatorial: Condutas Clínicas em Atenção Primária. 2 ed. Porto Alegre, Artes Médicas Sul, 1996. p.10-16.
35. ELASHOFF JD \& GROSSMAN MT - Trends in hospital admissions and deaths rates for peptic ulcer in the United States from 1970 to 1978. Gastroenterology 1980; 78:280-5.

36. KURATA JH, HAILE BM \& ELASHOFF JD - Sex differences in peptic ulcer disease. Gastroenterology 1985; 88:96-100.

37. LABENS J, LEVERKUS F \& BORSCH G - Omeprazole plus amoxicillin for cure of Helicobacter pylori infection. Factors influencing the treatment success. Scand J Gastroenterol 1994; 29: $1070-5$. 